\title{
Patterns and Determinants of Open Defecation among Urban People
}

\author{
Vera Yulyani $^{*}$, Christin Angelina Febriani ${ }^{1}$, Shaharudin MS², Dessy Hermawan ${ }^{3}$
}

\author{
${ }^{1}$ Department of Public Health, Faculty of Public Health, Universitas Malahayati, Bandar Lampung, Indonesia \\ ${ }^{2}$ Department of Environmental and Occupational Health, Faculty of Medicine and Health Science, Universitas Putera Malaysia, Selangor, \\ Malaysia \\ ${ }^{3}$ Department of Nursing, Faculty of Medicine, Universitas Malahayati, Bandar Lampung, Indonesia
}

\begin{abstract}
At the present time, million people still defecate in the open, not in private. Indonesia is a densely populated country with a lot of open defecation (OD) both in urban and rural areas. Tanjung Karang Pusat District is an area in Bandar Lampung City with the highest percentage of OD practice. This study aimed to explore and explained the patterns and determinants of OD among urban people in the Tanjung Karang Pusat District involving 377 respondents for quantitative analysis. Quantitative data were analyzed using chi-square and regression analysis. After controlling the economic status and education level variables, the data revealed that urban communities were still practicing $\mathrm{OD}(23.3 \%)$ with land ownership, latrine ownership, conative attitude, and occupation as influential factors. Statistical test results showed that the most influential factor in the behavior of $O D$ in the community was latrine ownership $(p$-value $<0.001, A O R=$ 58.2). These findings suggest that stakeholders must take action on landowners who do not allow sanitation facilities to be built on their land.
\end{abstract}

Keywords: open defecation, pattern, urban people

\section{Introduction}

An estimated 673 million people in 2017 still defecated in the open, not in private. This practice is known as open defecation (OD).1,2 There is always a high number of population (more than 58 million) in Indonesia still practicing open defecation both in urban areas and rural areas. ${ }^{3,4}$ Open defecation has a severe impact on children's health and contributes to a large number of premature deaths. ${ }^{5-9}$

In this day and age, there are still many people who practice OD. ${ }^{10}$ Technological developments and the easy exchange of information are no guarantees in changing peoples' behavior, even in urban areas with internet access. ${ }^{11-13}$ Tanjung Karang Pusat District, as a mother district in Bandar Lampung, has the highest number of OD. It is estimated that around $45 \%$ of the population in this subdistrict still practices OD using a plastic bag to defecate and dump it outside the home ("flying plastic"). In the same subdistrict, there are latrines without a connected septic tank. ${ }^{14}$

The Ministry of Health of the Republic of Indonesia has come up with a regulation known as the CommunityBased Total Sanitation (CBTS) since 2008. ${ }^{15}$ Thirty-four out of 126 villages in the city of Bandar Lampung have not done CBTS, and a further 90 out of 126 communities have not been declared Open Defecation Free (ODF). ${ }^{16}$ The Public Work Service also has a program on sanitation in urban communities known as Community Sanitation (Sanitasi Berbasis Masyarakat/SANIMAS). ${ }^{17}$ However, the complexity of OD problems in Bandar Lampung City continues to occur.

Several studies have determined the cause of OD, but this study will focus on rural areas; however, studies on urban areas are scarce. ${ }^{18-21}$ There has been a scant study to explore OD at municipal levels. ${ }^{22}$ The findings of the present study can be used to design or conduct follow up intervention of access sanitation and reduce OD in urban areas. Therefore, to answer this emerging gap in the background of this study, which aims to explore and explain the patterns and determinants of OD in urban areas, a cross-sectional survey was conducted to answer the questions in the jurisdiction of the Palapa Primary Health Care, Tanjung Karang Pusat District. The number of quantitative samples reached 377 respondents distributed across four subdistricts-Palapa, Kaliawi, Gotong Royong, and Durian Payung-in the Tanjung Karang Pusat District.
Correspondence ${ }^{*}$ : Vera Yulyani, Department of Public Health, Faculty of Public Health Universitas Malahayati, Rektorat Building 5th floor, Kemiling, Bandar Lampung 35152, Indonesia, E-mail:vera.yulyani@malahayati.ac.id, Phone: $+62-852-24416166$
Received : September 02, 2019

Accepted : August 13, 2020

Published: February 20, 2021 


\section{Method}

The community-based cross-sectional study design was utilized among the randomly selected households in the study area. The total population of this study was drawn from 7,707 entire families in the Tanjung Karang Pusat District located in the jurisdiction of the Palapa Primary Health Care. Quantitative sampling using the Lemeshow formula with p1 (0.62) and p2 (0.46) was utilized from the study conducted by Yulyani $\mathrm{V}$, et al. ${ }^{19,23}$

The minimum sample is 179 . However, based on the calculation, 377 households required to get a plausible result. Therefore, we took a sample of 377 to describe the population better. The samples were distributed across all four subdistricts among the working areas of the Palapa Primary Health Care using proportional random sampling (Table 1).

Subdistricts with higher population densities were sampled at proportionally higher rates. Purposive sampling was conducted after determining the number of samples required per subdistrict with inclusion criteria of households in the poverty pocket, and the respondents agreed to be involved in the study.

Two trained enumerators carried out this study in each subdistrict. The questionnaire was developed based on Precede Lawrence Green Model, the SaniFOAM framework, and previous studies. ${ }^{18,19,24}$ Education, economic status, occupation, land ownership, latrine access, and attitude (cognitive, affective, and conative) were the primary factors influencing health-related behaviors according to those references.

The open defecation behavior category was divided into "OD" and "Non-Open Defecation (Non-OD)". Level of education was divided into "None," "Elementary School," "Junior High School," and "Higher or equal than Senior High School.” The respondents' economic status category corresponded to "lower" if the total monthly household income was less than USD 175. Occupation is divided into "Unemployed" and "Employed". The status of land ownership was divided into "Rent" and "Private Property". Ownership of latrine was split into "None" and "Yes." The attitude category (cognitive, affective, and conative) was divided into "positive" and "negative," which identified a respondent having a positive attitude if the T-score is $\geq 50$.

Validity and reliability tests were undertaken on 30 households in the jurisdiction of Simpur Primary Health Care, Tanjung Karang Pusat District. The resulting questionnaire was found to be valid and reliable for use in this study. The results of the validity and reliability tests are used to test attitude questions with the following results:

a. Cognitive attitude: Initially, 10 question items became seven valid question items with corrected items total- ing more than $r$ table 0.361 .

b. Affective attitude: The number of questions conducted by the validity test was 13 questions with nine valid questions resulting in corrected items totaling more than $r$ table 0.361 .

c. Conative attitude: From a total of nine questions tested for validity, the number of valid questions was as many as six items with corrected items totaling more than $\mathrm{r}$ table 0.361 .

The chi-square test was used to describe cross-tabulation between variables OD and non-OD. The dependent variable is OD, while the independent variables are demographic, cognitive, affective, and conative attitudes. A binary logistic regression was used to determine the most dominant variable.

\section{Results}

Out of 377, an estimated 289 of the households used a latrine for defecation, and 88 families did not use a toilet. This section presents and discusses the relationships between the practice of OD and household socioeconomic, demographic and geographic factors in communities that are in the jurisdiction of the Palapa Primary Health Care. The factors that influence OD practice are presented in Table 2. The variables examined in this study include the level of education, economic status, occupation,

Table 1. Sample Size per Subdistrict of Tanjung Karang Pusat District

\begin{tabular}{lcr}
\hline Subdistrict & N & n \\
\hline Kaliawi & 1,046 & 107 \\
Palapa & 2,342 & 63 \\
Durian Payung & 1,387 & 157 \\
Gotong Royong & 2,932 & 50 \\
Total & 7,707 & 377 \\
\hline
\end{tabular}

Table 2. Descriptive Statistic of Variables Influencing Open Defecation

\begin{tabular}{llrr}
\hline Variable & Category & Frequency & Percentage \\
\hline Open Defecation (OD) & OD & 88 & 23.3 \\
behavior & Non-OD & 289 & 76.7 \\
Level of education & None & 21 & 5.5 \\
& Elementary school & 108 & 28.1 \\
& Junior high school & 97 & 25.2 \\
Economic status & Z Senior high school & 159 & 41.2 \\
& Lower & 177 & 53.8 \\
Occupation & Higher or equal & 152 & 46.2 \\
& Unemployed & 243 & 64.4 \\
Land ownership & Employed & 134 & 35.6 \\
\multirow{2}{*}{ Ownership of latrine } & Rent & 152 & 39.6 \\
\multirow{2}{*}{ Cognitive } & Private property & 232 & 60.4 \\
& None & 133 & 34.8 \\
Affective & Yes & 249 & 65.2 \\
& Negative & 191 & 49.6 \\
Conative & Positive & 194 & 50.4 \\
& Negative & 233 & 60.5 \\
& Positive & 152 & 39.5 \\
& Negative & 160 & 41.6 \\
& Positive & 225 & 58.4 \\
\hline
\end{tabular}


Table 3. Influencing Factors of Open Defecation

\begin{tabular}{|c|c|c|c|c|}
\hline \multirow{2}{*}{ Variable } & \multirow{2}{*}{ Category } & \multicolumn{2}{|c|}{ Open Defecation } & \multirow{2}{*}{ p-value } \\
\hline & & Open Defecation (\%) & Non Open Defecation (\%) & \\
\hline \multirow[t]{4}{*}{ Education } & No school & $9(10.2)$ & $11(3.8)$ & $<0.001$ \\
\hline & Elementary school & $47(53.4)$ & $59(20.4)$ & 0.957 \\
\hline & Junior high school & $24(27.3)$ & $69(23.9)$ & 0.092 \\
\hline & $\geq$ Senior high school & $8(9.1)$ & $150(51.9)$ & $<0.001$ \\
\hline \multirow{2}{*}{ Economic status } & $<\operatorname{USD} 171.5$ & $54(90)$ & $121(45.3)$ & $<0.001$ \\
\hline & $\geq \operatorname{USD} 171.5$ & $6(10)$ & $146(54.7)$ & \\
\hline \multirow{2}{*}{ Occupation } & Unemployed & $64(72.7)$ & 179 (61.9) & 0.064 \\
\hline & Employed & $24(27.3)$ & $110(38.1)$ & \\
\hline \multirow[t]{2}{*}{ Land ownership } & Rent & $82(95.3)$ & $47(16.3)$ & $<0.001$ \\
\hline & Private property & $4(4.5)$ & $241(83.7)$ & \\
\hline \multirow[t]{2}{*}{ Latrine ownership } & No & $82(95.3)$ & $47(16.3)$ & $<0.001$ \\
\hline & Yes & $4(4.7)$ & $241(83.7)$ & \\
\hline \multirow[t]{2}{*}{ Attitude: Cognitive } & Negative & $61(69.3)$ & $124(42.9)$ & $<0.001$ \\
\hline & Positive & $27(30.7)$ & $165(57.1)$ & \\
\hline \multirow[t]{2}{*}{ Attitude: Affective } & Negative & $55(62.5)$ & $174(60.2)$ & 0.794 \\
\hline & Positive & $33(37.5)$ & $115(39.8)$ & \\
\hline \multirow{2}{*}{ Attitude: Conative } & Negative & $61(69.3)$ & $93(32.2)$ & 0.000 \\
\hline & Positive & $27(30.7)$ & 196 (57.8) & \\
\hline
\end{tabular}

Table 4. Patterns and Determinants of Open Defecation in Urban People

\begin{tabular}{|c|c|c|c|c|c|c|}
\hline \multirow{2}{*}{ Variable } & \multirow{2}{*}{ Category } & \multirow{2}{*}{$\beta$} & \multirow{2}{*}{ p-value } & \multirow{2}{*}{ AOR } & \multicolumn{2}{|c|}{$\mathbf{9 5} \%$ CI for OR } \\
\hline & & & & & Lower Limit & Upper Limit \\
\hline Land ownership & Rent & 2.896 & $<0.001$ & 17.38 & 4.24 & 71.23 \\
\hline Latrine ownership & None & 4.065 & $<0.001$ & 58.28 & 13.49 & 251.73 \\
\hline Attitude: Conative & Negative & 1.473 & 0.013 & 4.37 & 1.36 & 14.03 \\
\hline Economic status & $<\operatorname{USD} 171.5$ & 0.080 & 0.918 & 1.08 & 0.23 & 4.99 \\
\hline Occupation & Unemployed & 1.201 & 0.048 & 3.32 & 1.01 & 10.90 \\
\hline \multirow[t]{4}{*}{ Education } & No School & & 0.012 & & & \\
\hline & Elementary school & 0.483 & 0.685 & 1.62 & 0.15 & 16.80 \\
\hline & Junior high school & -2.332 & 0.006 & 0.09 & 0.01 & 0.51 \\
\hline & $\geq$ Senior high school & -0.676 & 0.376 & 0.50 & 0.11 & 2.27 \\
\hline
\end{tabular}

Notes: $\mathrm{AOR}=$ Adjusted Odds Ratio; $\mathrm{CI}=$ Confidence Interval; OR = Odds Ratio; USD = US Dollar

land ownership, latrine ownership, attitude (cognitive, affective, and conative). The majority of respondents (76.7\%) did not practice OD, compared to the $23.3 \%$ who practiced OD. Most of the respondents $(41.2 \%)$ had completed higher or equal than senior high school, followed by those who completed elementary school $(28.1 \%)$, junior high school $(25.2 \%)$, and none $(5.5 \%)$. More than half of the respondents $(53.8 \%)$ had lower than regional minimum wage (USD 171.5). Most of the respondents $(64.4 \%)$ are unemployed, and the number of respondents who rent (or tenants) is $39.6 \%$. There were $34.8 \%$ of respondents who did not have a toilet.

Data on Table 3 indicates statistical significance variables that influence OD, such as economic status, land ownership, lantrine ownership, cognitive attitude, and attitude, have $p$-value $\leq 0.001$. Open defecation is not influenced by job status and affective attitude with a $\mathrm{p}$ value of more than $\alpha(0.05)$.

Tabel 4 shows that the most influence OD was latrine ownership (AOR $=58.28$ ). People who do not own a toi- let have 58 times more chance of doing OD than those who have a toilet. People whose lands are leased (AOR = 17.38) have 17 times more chance to do OD than those who own private land. Variables that are not included in the final model include cognitive and affective attitudes. The economic status $(\mathrm{AOR}=1.08)$ and education level $($ AOR Elementary school $=1.62$; Junior high school $=$ 0.09 ; Senior high school $=0.50$ ) variables were confounding variables in this study with $\mathrm{p}$-value more than $\alpha(0.05)$.

\section{Discussion}

Based on the results, approximately $23.3 \%$ of respondents practice OD. Findings from this study showed that OD in urban areas is caused by access and ownership of latrines not allowed by landowners. Access and availability of restrooms represent a key external or environmental factor. ${ }^{18}$ Allowing construction of sanitation facilities on leased land must be examined as a critical aspect in reducing OD in urban areas. ${ }^{25}$ These results are in line 
with a previous study conducted in Ghana where OD was reduced when there is access to the toilet. ${ }^{26}$ Attitude and injunctive norm are the psychological predictors of latrine ownership, and consistent latrine use was associated with attitude, cleanliness of the latrine, and its privacy. ${ }^{27}$

Logistic regression analysis shows that the most influential factor in OD behavior is latrine ownership ( $\mathrm{p}$-value $<0.001, \mathrm{AOR}=58.28$ ). These results are in line with a research conducted in India on urban communities where the leading cause of OD is access to water and sanitation facilities. ${ }^{28}$ Social networks such as caste, education, and income influence the ownership of a toilet. ${ }^{29}$ The results of this study are in line with the study that has been done where people who do not have latrines are indeed in the same area with similar social characteristics.

Building latrines at the household level is very important in eliminating OD. ${ }^{30}$ The construction dependents on education, soil conditions, social cohesion, the perception that many other community members have a restroom, and high confidence in personal abilities. ${ }^{31}$ The interventions so far carried out by the Ministry of Health are always focused mostly on individual-level determinants such as attitudes and behavior, instead of considering all possible social determinants of latrine ownership. ${ }^{32}$

Public toilets built by stakeholders are often grossly inadequate and of low quality that shortly after commissioning, maintenance provision was not part of the contracts. ${ }^{2}$ Providing communal toilets can reduce but not end the problem of OD in urban poverty pockets. ${ }^{33}$ What is interesting in the latrine ownership data is that there are people who already have latrines but are still practicing OD $(4.7 \%)$ because usually they live near the river, and OD has become a habit. Health authorities must continue to promote and raise awareness about the importance of using latrines. ${ }^{34-36}$

Toilet ownership is usually related to the respondent's land ownership status. The results of in-depth interviews show that most landowners do not allow septic tanks to be built because they are still leasing the land they live in. Furthermore, if the land is located in a mountainous area and the ground is perforated in building septic tanks, the landowner fears this could cause landslides and reduce the selling price of land. The study indicates that latrine ownership is a variable that needs to be considered in lowering OD in urban poverty areas. The result is identical to earlier literature, which found that dwelling space and household latrine ownership are important conditions that reduce OD. 32

Intending to increase ODF areas, from the results of this study, it is necessary that the city government implement a firm policy that every house occupied should be equipped with sanitation facilities. This study also found that people are concerned about the difficulty of siphoning a toilet. Mountainous areas with very dense houses will make it difficult for people to siphon septic tanks. Urban poor communities are more likely to be affected by these problems-siphoning and constructing the septic tank. ${ }^{28}$ A modern technology that does not pollute the environment is needed so that this complex sanitation problem can be resolved.

The Public Works Department has a work program that focuses on sanitation installations in urban areas known as SANIMAS. ${ }^{17}$ Meanwhile, the Ministry of Health's CBTS is a program that focuses on interventions to change values and people's beliefs about sanitation. ${ }^{37}$ The integration of the two programs will result in new sanitation technologies that will improve sanitation access for the city's communities.

There is a need for a policy shift toward empowering households and communities, especially in collaboration with landowners, to help resolve OD together. ${ }^{38}$ This study has some significant limitations. It is based on the bias in data collection resulting from a non-random sample. This sampling technique can illustrate the real reason respondents who are in poverty pockets in urban areas practice OD.

\section{Conclusion}

People in urban communities still defecate in the open, and the main factor is the ownership of latrines, especially among immigrants whose ownership status is that of a tenant. City governments should promote policies ensuring that every house, owned or rented, must be equipped with sanitation facilities. This program can work well if it involves communities, local stakeholders, and landowners. Suggestions for further research should determine to what extent the city government is committed to improving access to sanitation, reducing the number of ODs.

\begin{abstract}
Abbreviations
OD: Open Defecation; CBTS: Community-Based Total Sanitation; ODF: Open Defecation Free; SANIMAS: Sanitasi Berbasis Masyarakat (Community Sanitation); Non-OD: Non-Open Defecation; AOR: Adjusted Odds Ratio.
\end{abstract}

\section{Ethics Approval and Consent to Participate}

The study ethics was obtained from the Ethics Committee Politeknik Kesehatan Tanjungkarang with the study protocol code 147/EA/KEPKTJK/V/2019.

\section{Competing Interest}

The author declares that there is no significant competing financial, professional, or personal interest that might have affected the performance or presentation of the work described in this manuscript. 


\section{Availability of Data and Materials}

The data supporting the findings and the material of this study are available on request from the corresponding author. The data are not publicly available due to information that could compromise the research participant's privacy/consent.

\section{Authors' Contribution}

VY has devised the project, the main conceptual ideas, the proof outline, also worked out the technical and quantitative study. CAF worked out technical details on qualitative research. SMS made corrections in English and improved the manuscripts. DH supervised the findings of his work. All authors discussed the results and contributed to the final manuscript.

\section{Acknowledgment}

The authors would like to thank the respondents who gave valuable information and participated in this study. Gratitude to interviewers (public health sanitarians from Palapa Primary Health Care and cadre) involved in data collection and the District Health Office of Bandar Lampung City and Malahayati University for permitting us to conduct the study.

The District Health Office authorized the study in Tanjung Karang, the Head of the Palapa Primary Health Care, the Head of the Bandar Lampung National Unity and Politics Agency, and Malahayati University.

This study was supported by funding from the Directorate General of Higher Education (Direktorat Jenderal Pendidikan Tinggi) of the Ministry of Education and Culture (Kementerian Pendidikan dan Kebudayaan) of the Republic of Indonesia in 2019.

\section{References}

1. Steele R. Progress on household drinking water, sanitation and hygiene. New York: WHO/UNICEF Joint Monitoring Programme for Water Supply and Sanitation (JMP). 2019; 140: 2000-17.

2. Grojec A. Progress on sanitation and drinking water (2015 update and MDG assessment). Switzerland: UNICEF and World Health Organization; 2015.

3. World Bank. Water supply and sanitation in Indonesia service delivery assessment turning finance into services; 2015.

4. Cameron LA, Shah M. Scaling up sanitation: evidence from an RCT in Indonesia. Arc Discovery Projects. 2017; 10619: 34.

5. Mara D. The elimination of open defecation and its adverse health effects: a moral imperative for governments and development professionals. Journal of Water, Sanitation \& Hygiene for Development. 2017; 7 (1): 1-12.

6. M Yalew BM. Prevalence and factors associated with stunting, underweight, and wasting: a community based cross sectional study among children age 6-59 months at Lalibela town, Northern Ethiopia. Journal of Nutritional Disorders \& Therapy. 2014; 04 (2).

7. Vyas S, Kov P, Smets S, Spears D. Disease externalities and net nutrition: evidence from changes in sanitation and child height in Cambodia, 2005-2010. Economics \& Human Biology. 2016; 23: 23545.

8. Clasen T, Boisson S, Routray P, Torondel B, Bell M, Cumming O, et al. Effectiveness of a rural sanitation programme on diarrhea, soiltransmitted helminth infection, and child malnutrition in Odisha, India: a cluster-randomised trial. Lancet Global Health. 2014; 2 (11): e645-53.

9. Spears D. Exposure to open defecation can account for the Indian enigma of child height. Journal of Development Economics. 2018; 146: $1-17$.

10. World Health Organization. World health statistics: monitoring health for the SDGs. Switzerland: World Health Organization; 2016.

11. Chaudhuri S, Roy M. Rural-urban spatial inequality in water and sanitation facilities in India: a cross-sectional study from household to national level. Applied Geography. 2017; 85: 27-38.

12. Abubakar IR. Exploring the determinants of open defecation in Nigeria using demographic and health survey data. Science of the Total Environment. 2018; 637-8: 1455-65.

13. Heijnen M, Routray P, Torondel B, Clasen T. Shared sanitation versus individual household latrines in urban slums: a cross-sectional study in Orissa, India. American Journal of Tropical Medicine and Hygiene. 2015; 93 (2): 263-8.

14. Kementerian Kesehatan Republik Indonesia. Sanitasi LKA; 2019.

15. Pelaksanaan P. Sanitasi total berbasis masyarakat dalam Program Kesehatan dan Gizi Berbasis Masyarakat (PKGBM); 2015.

16. Kementerian Kesehatan Republik Indonesia. Laporan kemajuan ODF; 2019.

17. Direktorat Jenderal Cipta Karya Kementerian Pekerjaan Umum dan Perumahan Rakyat Republik Indonesia. Petunjuk teknis SANIMAS reguler; 2017.

18. O'Connell K. Water and sanitation program. What influences open defecation and latrine ownership in rural households?: findings from a global review; 2014. p.38.

19. Vera Yulyani, Dina Dwi N, Dina Kurnia. Latrine use and associated factors among Rural Community in Indonesia. Malaysian Journal of Public Health Medicine. 2019; 19 (1): 143-51.

20. Daley K, Castleden H, Jamieson R, Furgal C, Ell L. Water systems, sanitation, and public health risks in remote communities: Inuit resident perspectives from the Canadian Arctic. Social Science \& Medicine. 2015; 135: 124-32.

21. Kayoka C, Itimu-Phiri A, Biran A, Holm RH. Lasting results: a qualitative assessment of efforts to make community-led total sanitation more inclusive of the needs of people with disabilities in Rumphi District, Malawi. Disability and Health Journal. 2019; 12 (4): 10-3.

22. Abramovsky L, Augsburg B, Flynn E, Oteiza F. Improving CLTS targeting: evidence from Nigeria. Economic \& Social Research Council. 2016.

23. Ryan TP. Sample size determination and power. United States: Wiley; 2013. p. $1-374$

24. Windsor RA. Evaluation of health promotion and disease prevention programs. Fifth edition. Madison Avenue: Oxford University Press; 2015.

25. O'Reilly K. The influence of land use changes on open defecation in rural India. Applied Geography. 2018; 99: 133-9.

26. Nunbogu AM, Harter M, Mosler HJ. Factors associated with levels of latrine completion and consequent latrine use in Northern Ghana. International Journal of Environmental Research and Public Health. 
2019; 16 (6): 920.

27. Alemu F, Kumie A, Medhin G, Gasana J. The role of psychological factors in predicting latrine ownership and consistent latrine use in rural Ethiopia: a cross-sectional study. BMC Public Health. 2018; 18: 229.

28. Wankhade K. Urban sanitation in India: key shifts in the national policy frame. Environmentalist and Urban. 2015; 27 (2): 555-72.

29. Shakya HB, Christakis NA, Fowler JH. Social network predictors of latrine ownership. Social Science \& Medicine. 2015; 125: 129-38.

30. Park MJ, Clements ACA, Gray DJ, Sadler R, Laksono B, Stewart DE. Quantifying accessibility and use of improved sanitation: towards a comprehensive indicator of the need for sanitation interventions. Scientific Reports. 2016; 6 (October 2015): 1-7.

31. Mosler HJ, Mosch S, Harter M. Is community-led total sanitation connected to the rebuilding of latrines? quantitative evidence from Mozambique. PLOS ONE. 2018; 13 (5): e0197483

32. Jain A, Fernald LCH, Smith KR, Subramanian SV. Sanitation in rural India: Exploring the associations between dwelling space and household latrine ownership. International Journal of Environmental Research and Public Health. 2019; 16 (5): 734.

33. Shiras T, Cumming O, Brown J, Muneme B, Nala R, Dreibelbis R.
Shared latrines in Maputo, Mozambique: exploring emotional well-being and psychosocial stress. BMC International Health Human Rights. 2018; 18: 30.

34. Patil SR, Arnold BF, Salvatore AL, Briceno B, Ganguly S, Colford JM, Gertler PJ. The effect of India's total sanitation campaign on defecation behaviors and child health in rural Madhya Pradesh: a cluster randomized controlled trial. PLOS Medicine. 2015; 11 (8): e1001709.

35. Dickey MK, John R, Carabin H, Zhou XN. Program evaluation of a sanitation marketing campaign among the Bai in China: a strategy for cysticercosis reduction. Social Marketing Quarterly. 2015; 21 (1): 3750.

36. Bardosh K. Achieving "total sanitation" in rural African geographies: Poverty, participation and pit latrines in Eastern Zambia. Geoforum. 2015; 66: 53-63.

37. Kementerian Kesehatan Republik Indonesia. Peraturan Menteri Kesehatan Republik Indonesia Nomor 3 Tahun 2014 Tentang Sanitasi Total Berbasis Masyarakat; 2014.

38. Desai R, Mcfarlane C, Graham S. The politics of open defecation: Informality, body, and infrastructure in Mumbai. Antipode. 2015; 47 (1): 98-120. 